\title{
Effects of flooding regime and diel cycle on diet of a small sized fish associated to macrophytes
}

Efeitos do regime hidrológico e do ciclo diário na dieta

de uma espécie de pequeno porte associada à macrófitas

\author{
Natália Carniatto ${ }^{1}$, Rosemara Fugi ${ }^{1}$, Geuza Cantanhêde ${ }^{2,3}$, \\ Éder André Gubiani ${ }^{2}$ and Norma Segatti Hahn ${ }^{1}$
}

${ }^{1}$ Núcleo de Pesquisas em Limnologia, Ictiologia e Aquicultura - NUPELIA, Programa de Pós-graduação em Ecologia de Ambientes Aquáticos Continentais - PEA, Universidade Estadual de Maringá - UEM,

Av. Colombo, 5790, CEP 87020-900 Maringá, PR, Brazil

e-mail: nati_carniatto@hotmail.com; rosemarafugi@gmail.com; hahnns@nupelia.uem.br

${ }^{2}$ Grupo de Pesquisas em Recursos Pesqueiros e Limnologia, Programa de Pós-graduação em Recursos

Pesqueiros e Engenharia de Pesca, Universidade Estadual do Oeste do Paraná - UNIOESTE,

Rua da Faculdade, 645, CEP 85903-000, Toledo, PR, Brazil

e-mail: geuzac@yahoo.com.br; egubiani@yahoo.com.br

${ }^{3}$ School of Health and Biosciences, Pontifical Catholic University of Parana - PUCPR, Av. da União, 500, Jardim Coopagro, CEP 85902-532, Curitiba, PR, Brazil

\begin{abstract}
Aim: In this paper we assessed the effects of flooding (low and high water period) on the feeding activity and diet composition of Serrapinus notomelas in patches of the macrophyte Eichhornia azurea in a shallow floodplain lake (upper Paraná River Floodplain, Brazil). We also assessed the variations of diet composition and feeding activity along the diel cycle. Methods: Traps were used to catch the fish inside of macrophyte patches monthly from June/2007 to May/2008. A total of 1038 stomachs were examined. We assessed the feeding activity with the mean stomach fullness degree method. To summarize and support the results of diet composition in the different periods (low and high water periods) and times (dawn, light period, and dusk), was applied a nonmetric multidimensional scaling (NMS). Results: The feeding activity of $S$. notomelas did not differ between low and high water periods, but it differed along the diel cycle. The feeding activity was higher during the light period and dusk, at both the low and high water period. The diet composition differed significantly between low and high water periods, and also along the diel cycle. In the low water the diet of S. notomelas was composed mainly by algae and in the high water by Cladocera. Algae were consumed mainly during the light period while Cladocera in dawn and dusk. Conclusions: Our results indicate that the oscillations in the water level affect the diet composition, but not the feeding activity of $S$. notomelas. These seasonal changes are probably related to the temporal abundance of food resources, thus, when Cladocera density was low (low water), $S$. notomelas consumed mainly algae but when Cladocera was more abundant (high water), it became a common food resource.
\end{abstract}

Keywords: Serrapinus notomelas, feeding activity, Paraná River, Eichhornia azurea.

Resumo: Objetivo: Neste estudo nós avaliamos os efeitos do regime hidrológico (seca e cheia) e do ciclo diário (horários) na atividade alimentar e na composiçâo da dieta de Serrapinus notomelas em bancos de Eichhornia azurea em um ambiente raso da planície de inundação do alto rio Paraná, Brasil. Métodos: Os peixes foram amostrados mensalmente, entre junho/2007 e maio/2008, com armadilhas colocadas dentro dos bancos de macrófitas. Foram examinados 1038 estômagos. A atividade alimentar foi avaliada através do grau de enchimento médio dos estômagos. Para sumarizar e interpretar os resultados da composição da dieta por período (seca e cheia) e ciclo diário (horários) foi aplicada uma NMS. Resultados: A atividade alimentar de S. notomelas não diferiu significativamente entre os períodos de seca e cheia, mas foi significativamente diferente durante o ciclo diário. A atividade alimentar foi mais intensa no período diurno e ao entardecer tanto na seca quanto na cheia. Diferenças significativas na composição da dieta foram verificadas, entre os períodos de seca e cheia, e entre os horários do dia. $\mathrm{Na}$ seca, a dieta de $S$. notomelas foi composta principalmente por algas e na cheia por Cladocera. As algas foram consumidas mais intensamente no período diurno e Cladocera ao amanhecer 
e ao entardecer. Conclusóes: Nossos resultados indicam que o regime hidrológico afeta a composiçáo da dieta de $S$. notomelas, mas não afeta a atividade alimentar. As variaçóes sazonais na composição da dieta provavelmente estão associadas às variaçóes temporais na abundância dos recursos alimentares regidas pelo regime hidrológico. Assim, quando a densidade de Cladocera foi baixa (seca), S. notomelas consumiu predominantemente algas, mas quando Cladocera foi abundante (cheia) passou a ser um recurso alimentar importante para $S$. notomelas.

Palavras-chave: Serrapinus notomelas, atividade alimentar, Rio Paraná, Eichhornia azurea.

\section{Introduction}

Aquatic macrophytes mediate ecological interactions in freshwater ecosystems (Savino and Stein, 1982; Pelicice and Agostinho, 2006; Thomaz et al., 2008; Dibble and Pelicice, 2010) and thus, this vegetation is an important component of freshwater habitats. The upper Paraná River and its floodplain are highly colonized by several species of macrophytes, especially Eichhornia azurea (SW.) Kunth, which occurs in channels, lakes and backwaters in high biomasses (Bini, 1996).

High fish abundances and diversity are recorded inside macrophyte patches in this floodplain (Agostinho et al., 2007; Dibble and Pelicice, 2010; Cunha et al., 2011). The structural complexity provided by these plants can strongly mediate the competitive and predatory interactions by providing prey refuges, sustaining more diverse communities (Meerhoff et al., 2007; Padial et al., 2009). In addition, submersed structures of macrophytes provide adequate substrate for bacteria, algae and detritus which contribute to increase invertebrate abundance associated to these plants (Junk, 1973; Melo et al., 2002; Rodrigues and Bicudo, 2004; Thomaz et al., 2008; Mormul et al., 2010). As a consequence, fish benefit in such habitats by elevated diversity and quantity of food (Casatti et al., 2003; Pelicice and Agostinho 2006; Kovalenko et al., 2009). For example, Loureiro-Crippa et al. (2009) showed that autochthonous resources were the most exploited type of food by six small fish species in the upper Paraná floodplain, and that aquatic macrophytes provide these foods.

The hydrological regime is considered a key factor in river floodplain systems and the alternation between flooding and drought periods determine the structure and functioning of these systems (Junk et al., 1989; Thomaz et al., 2007). In the upper Paraná River floodplain the pattern of abundance of benthic and zooplankton invertebrates, important food for fish, is strongly affected by the periodic fluctuations in water level (Takeda and Fujita, 2004; Lansac-Tôha et al., 2004). The connectivity between habitats increases during the flood allowing exchange of nutrients and organisms among them (Thomaz et al., 2007). In this period it is expected an increase in the availability of allochthonous food resources and a reduction of the autochthonous food supply, thus the floods change the nature of the available food (Abujanra et al., 2009). In fact, several studies have shown the effects of the water levels on fish diet composition in floodplain ecosystems (Almeida et al., 1997; Luz-Agostinho et al., 2008), and on the feeding activity (Luz-Agostinho et al., 2009).

Temporal variation in fish activity (Pelicice and Agostinho, 2006; Gelós et al., 2010) can also occur along diel cycles. According to Pelicice and Agostinho (2006) patterns of diel activity can be associated to feeding behavior or mechanisms to avoid predation. Despite the studies about the seasonal (e.g., Almeida et al. 1997; Hahn and Loureiro-Crippa, 2006) and diel (e.g., Pelicice and Agostinho 2006) variations in fish feeding activity and/or composition, these studies rarely measure changes in both temporal scales simultaneously for a same fish species.

In this investigation we assessed the use of food resources by Serrapinus notomelas (Eigenmann, 1915) that colonizes patches of the macrophyte Eichhornia azurea. This fish species is a small Characidae (sub-family Cheirodontinae) that is rarely longer than $40 \mathrm{~mm}$, and shows high abundances in lakes in the upper Paraná River floodplain, in part due to their opportunistic life strategy (they present multiple spawning and mature quickly) (Piana et al., 2006). Considering the importance of macrophytes as forage habitat for small fishes and that the flooding regime can alter the composition and quantity of food resources available to the fish, the goal of this paper was to test if flooding regime affects the feeding activity and diet composition of Serrapinus notomelas. In addition, variations of diet composition and feeding activity along the diel were also assessed. 


\section{Material and Methods}

Our samplings were carried out in a shallow lake (Leopoldo backwater) in an island of the Upper Paraná River Floodplain, Brazil (22 45' $24^{\prime \prime} \mathrm{S}$ and $53^{\circ} 16^{\prime} 08^{\prime \prime}$ W; Figure 1), to which it is permanently connected through a canal. Its shores are colonized by forest, with predominance of trees of the genera Croton, Cecropia and Inga. The littoral zone is colonized mainly by Eichhornia azurea (the dominant species), E. crassipes (Mart.) Solms, Salvinia auriculata Aubl., Oxicaryum cubense (Poeppig \& Kunth) and Polygonum spp.

Samplings were carried monthly from June 2007 to May 2008; this period corresponds to low water (June-November 2007) and high water (December 2007 to May 2008) periods. These periods represent quite well also less and high precipitation, respectively.

Eichhornia azurea patches were selected as sampling habitats. This is a rooted macrophyte with long floating stems, roots at the nodes and emergent leaves. This plant was dominant in the lake thorough the sampling period. We sampled fish with Plexiglas box-like traps (minnow traps kind; see details in Dibble and Pelicice, 2010). These traps remain floating and are specially designed to sample the layer close to water surface, where macrophytes roots and stems are concentrated. Three traps were used in each sampling occasions (totalizing 36 samplings) and they remained for 24 hours inside the patches. To assess diel variations in feeding activity and diet composition fish were collected at every four hours (7:00 AM, 11:00 AM, 3:00 PM, 7:00 PM, 11:00 PM and 3:00 AM). Fishes were anaesthetized with eugenol and fixed in $10 \%$ formalin, and voucher specimens were deposited at the Museum of the Universidade Estadual de Maringá, Paraná State. Nup. 6283.

All fish were identified, counted and measured (standard length); after fish evisceration a numerical scale was used to assess (by visual inspection) the

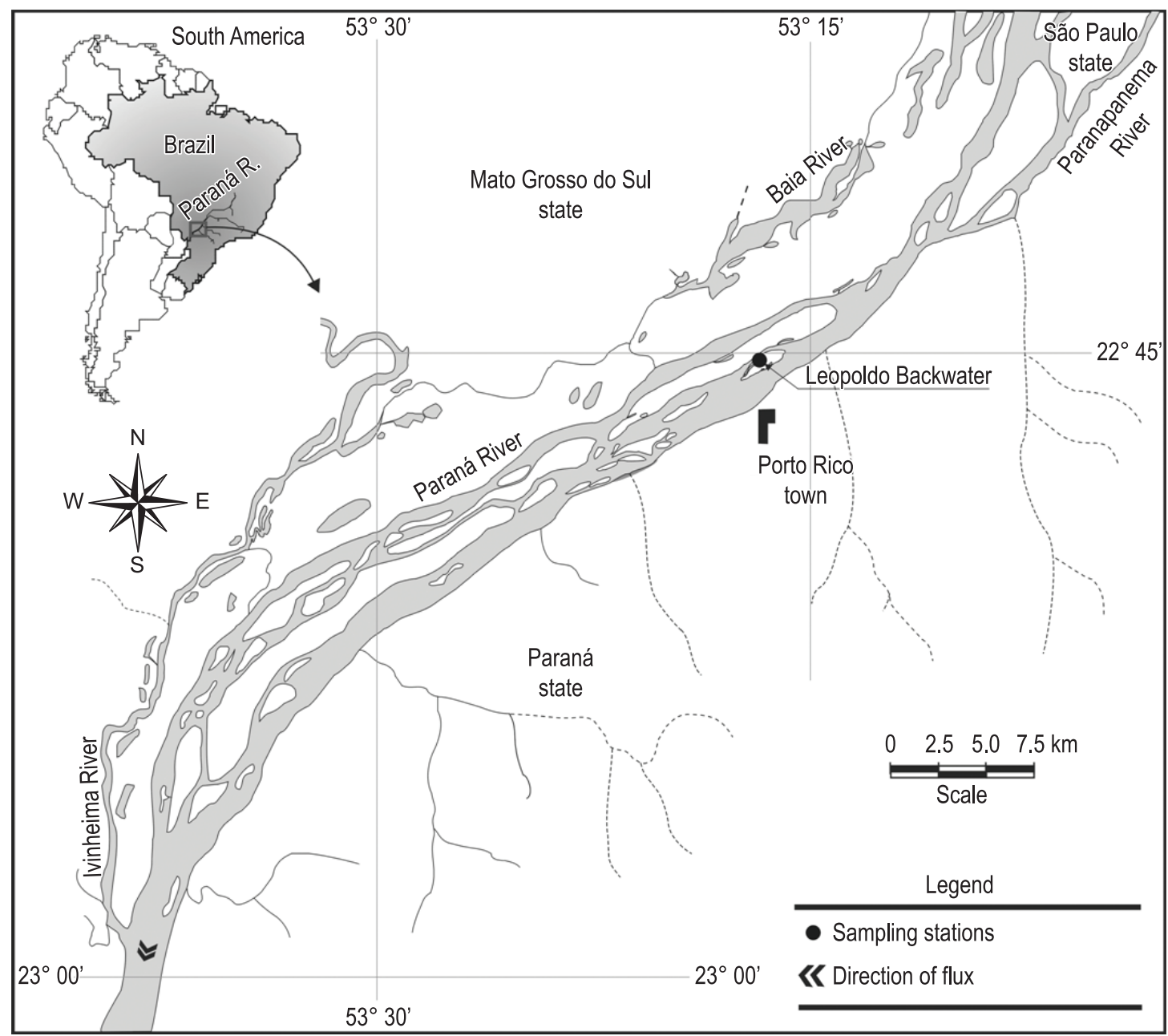

Figure 1. Study area and location of the sampling site in the upper Paraná River floodplain, Brazil. • Leopoldo backwater. 
degree of stomach's fullness: $0=$ empty stomach; $1=1-25 \%$ of stomach volume occupied by food; $2=25-75 \%$; and $3=75-100 \%$. Stomachs classified as 2 or 3 were preserved in $4 \%$ formalin for diet analyses. A total of 1038 stomachs were examined. Diet was assessed in 561 stomachs contents (which had 2 or 3 degree of fullness) by the volumetric method, which expresses the relationship between the volume of a given food item and the total volume of all food items, as a percentage (Hyslop, 1980). Food items were determined to the most detailed taxonomic level possible.

The feeding activity was assessed by the mean stomach fullness (Msf), expressed by: $M s f=\left(\mathrm{N}_{0}{ }^{*} 0\right)+\left(\mathrm{N}_{1}{ }^{*} 1\right)+\left(\mathrm{N}_{2}{ }^{*} 2\right)+\left(\mathrm{N}_{3}{ }^{*} 3\right) / N$, where $\mathrm{N}_{0}, \mathrm{~N}_{1}, \mathrm{~N}_{2}$ and $\mathrm{N}_{3}$ correspond to the number of individuals with stomach fullness of $0,1,2$ and 3 , respectively, and $N$ is the total number of analyzed individuals.

To assess whether there were differences between the mean stomach fullness, we applied two-way ANOVAs: Factor 1: periods (low and high water); Factor 2: times (dawn (7:00 AM), light period (11:00 AM and 3:00 PM), and dusk (7:00 PM)); and their interaction. The assumptions of normality and homoscedasticity were tested using the Shapiro-Wilk and Levene tests, respectively. When the interaction of the two-way ANOVA was not significant, we applied a Tukey test to determine which level differed.

To summarize and support the results of diet composition in the different periods (low and high water periods) and times (dawn, light period, and dusk), was applied a nonmetric multidimensional scaling (NMS) (Kruskal, 1964). Sorensen distances were computed and the general NMS procedure outlined by McCune and Grace (2002) was adopted. Random starting configurations were used, the number of runs with the real data was 100 and the stability criterion was standard deviations $\leq 0.005$ in stress over 100 iterations. This analysis was performed on the data matrix of total volume of each item in both hydrological periods and diel times. To test the significance of between-group differences a permutational multivariate analysis of variance (PERMANOVA; Anderson, 2001) was used on the transformed data with Bray-Curtis dissimilarities between samples. Two-factor permutations were used to identify significant differences among periods and times, and their interactions. The sampling design has to be balanced to apply PERMANOVA and thus, we used a sub-sampling applying the option "subset/ random" of the software Statistica 7.0. NMS and PERMANOVA were computed using the software PC-Ord ${ }^{\oplus}$ 5.0. The statistical significance level adopted was $\mathrm{p}<0.05$.

\section{Results}

\subsection{Feeding activity}

A total of 1038 stomachs (905 in low water and 133 in high water) were analyzed: 205 in the dawn, 648 in the light period, and 143 in the dusk. The samplings corresponding to 11:00 PM and 3:00 AM were excluded because of the small number of individuals captured (total of 42). The mean stomach fullness values did not differ between low and high water periods $\left(\mathrm{F}_{1: 33}=0.48\right.$, $\mathrm{p}=0.496$; Figure 2). Considering the diel cycle,

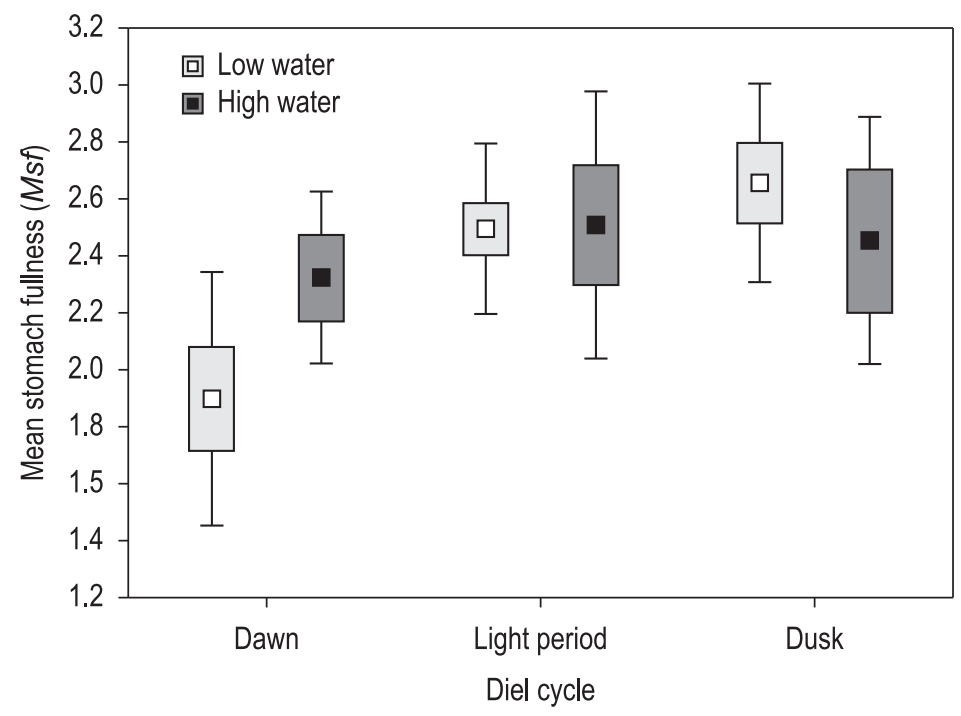

Figure 2. Seasonal and diel feeding activity of Serrapinus notomelas sampled in patches of Eichhornia azurea between June 2007 and May 2008. Middle point = mean value; Box = standard error; and whiskers = standard deviation. 
the mean stomach fullness was higher during the light and dusk period in both low and high water period (Figure 2). The light period and dusk differed significantly from the dawn, in both low and high water period $\left(\mathrm{F}_{1.33}=4.22, \mathrm{p}=0.024\right.$; Tukey's test $\mathrm{p}<0.05$; Figure 2).

\subsection{Diet composition}

The most consumed food item by $S$. notomelas in the low water period (455 stomach contents analyzed) was algae, which represented more than $70 \%$ of the diet in all months except September (47.2\%) (Table 1). Cyanophyceae predominated in June (54.6\%), July (32.3\%) and October (49.4\%), Zignemaphyceae in August (29.1\%), and November (37.4\%). Cladocera was the most consumed item in September (41.4\%). In the high water period (117 stomach contents analyzed), S. notomelas consumed predominantly Cladocera (mainly Diaphanosoma spp., Daphnia spp. and Moina spp.) This item represented more than $80 \%$ of the diet in January, February and April (Table 1). In December and May Cladocera represented 25.4 and $13.4 \%$ of the diet, respectively. In these last two months, the species consumed mainly algae Zignemaphyceae (52\% and 69.3\%). In March S. notomelas was not catch.

Diel changes in the diet of $S$. notomelas were also observed, with higher consume of algae in the light period (55.98\% - 297 stomach contents analyzed) and an increase in the consume of Cladocera in the dusk (60.24\% 125- stomach contents analyzed) and dawn (70.8\% - 139 stomach contents analyzed) (Table 2).

Nonmetric multidimensional scaling summarized diet composition and separated low and high water. After 54 iteractions, the stability criterion was met with a final stress of 26.11 (Monte Carlo test: $p=0.006$ ) for 2-dimensional solution. The proportion of variance represented by each axis, based on the $\mathrm{r}^{2}$ between distance in the ordination space and distance in the original space was 0.34 for axis 1 and 0.22 for axis 2 , totalling 0.56 . Low and high water periods were separated along NMS axis 1 (Figure 3a). The diet in the low water was composed mainly of algae, while in the high water it was predominantly composed by invertebrate, especially Cladocera (Figure 3c). Separation of diel times along axes was not clear (Figure 3b); however, in the light period $S$. notomelas consumed mainly algae, and in the dawn and dusk it consumed predominantly Cladocera (Figure 3c; Table 2).

PERMANOVA based on the Bray-Curtis distances detected a significant difference among periods (Pseudo-F $=23.13$, Pperm $=0.0002$ ) and diel times (Pseudo-F $=8.54$, Pperm $=0.0002$ ). However, the interaction was significant (Pseudo-F $=3.89$, Pperm $=0.0002)$. Pairwise comparisons (Method 1 - Other factor and interaction partitioned out; Anderson, 2001) showed that diet composition in the dawn was significantly different from the light and dusk periods (Table 3).

\section{Discussion}

The high complexity of the E. azurea roots (Dibble and Thomaz, 2006) may partially explain the high density of $S$. notomelas associated to this macrophyte, because it provides greater protection against predators. In addition, because of their structural complexity, the roots of this plant

Table 1. Seasonal changes in diet composition (\% of volume) of Serrapinus notomelas sampled in patches of Eichhornia azurea between June 2007 and May 2008.

\begin{tabular}{|c|c|c|c|c|c|c|c|c|c|c|c|}
\hline \multirow{2}{*}{ Food items } & \multicolumn{6}{|c|}{ Low water } & \multicolumn{5}{|c|}{ High water } \\
\hline & June & July & Aug & Sept & Oct & Nov & Dec & Jan & Feb & Apr & May \\
\hline Algae & 77.5 & 74.1 & 74.7 & 47.2 & 76.5 & 84.7 & 60.7 & 10.3 & 14.5 & 0.8 & 82.3 \\
\hline Cyanophyceae & 54.6 & 32.3 & 7.5 & 3.0 & 49.4 & 20.0 & 0.8 & 0.5 & 3.5 & & 9.0 \\
\hline Zignemaphyceae & 17.7 & 23.8 & 29.1 & 25.8 & 17.4 & 37.4 & 52.0 & 6.0 & 6.4 & 0.4 & 69.3 \\
\hline Chlorophyceae & 1.2 & 0.1 & 2.6 & 0.8 & 0.3 & 2.3 & 0.6 & & 0.2 & & \\
\hline Oedogonophyceae & 2.8 & 16.2 & 26.0 & 14.9 & 8.6 & 21.9 & 7.2 & 3.1 & 4.3 & & 3.4 \\
\hline Bacillariophyceae & 0.9 & 1.2 & 8.4 & 2.7 & 0.8 & 3.1 & 0.1 & 0.3 & 0.1 & 0.4 & 0.6 \\
\hline Other algae & 0.3 & 0.5 & 1.1 & * & & & & 0.4 & & & \\
\hline Invertebrate & 22.6 & 25.9 & 25.2 & 52.8 & 23.6 & 15.3 & 39.1 & 89.6 & 85.5 & 99.2 & 17.6 \\
\hline Testate amoebae & 0.1 & 3.1 & 8.4 & 4.7 & 1.0 & 0.5 & 2.9 & & 0.1 & & 0.7 \\
\hline Rotifera & 0.1 & 0.3 & 0.1 & 0.4 & 0.5 & 1.0 & 1.8 & 0.1 & 0.1 & 4.3 & 0.9 \\
\hline Copepoda & 0.9 & 0.2 & 0.3 & 0.4 & & 0.4 & 2.3 & * & 0.6 & & 0.6 \\
\hline Cladocera & 19.5 & 19.7 & 9.3 & 41.4 & 16.6 & 7.6 & 25.4 & 89.3 & 84.7 & 82.1 & 13.4 \\
\hline Diptera & 2.0 & 2.6 & 6.2 & 4.0 & 4.1 & 5.1 & 4.8 & 0.2 & & 8.5 & \\
\hline Other invertebrate ${ }^{* *}$ & & & 0.9 & 1.9 & 1.4 & 0.7 & 1.9 & & * & 4.3 & 2.0 \\
\hline
\end{tabular}

${ }^{*}=$ values $<0.01 ;{ }^{* *}$ Hydracarina, Bryozoa, Ostracoda and Ephemeroptera. 

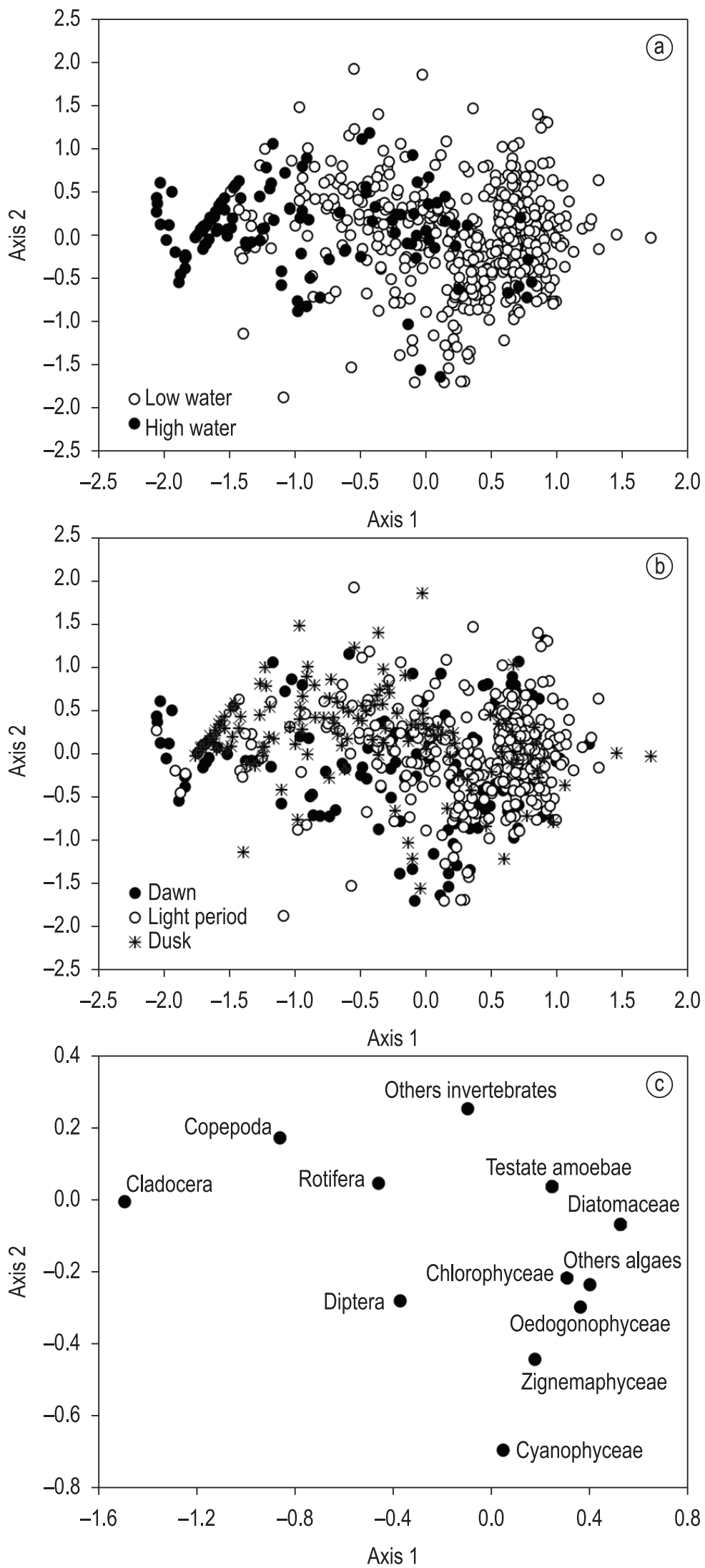

Figure 3. Nonmetric multidimensional scaling (NMS) ordination of the periods (a), times (b) and food items (c) for Serrapinus notomelas sampled in patches of Eichhornia azurea between June 2007 and May 2008. Only significant axes are shown (Axis 1 versus Axis 2). 
Table 2. Diel changes in diet composition (\% of volume) of Serrapinus notomelas sampled in patches of Eichhornia azurea between June 2007 and May 2008.

\begin{tabular}{lrrr}
\hline \multirow{2}{*}{ Food items } & \multicolumn{3}{c}{ Time } \\
\cline { 2 - 4 } & Dawn & Light & Dusk \\
\hline Algae & $\mathbf{2 9 . 1 9}$ & $\mathbf{5 5 . 9 8}$ & $\mathbf{3 9 . 7 6}$ \\
Cyanophyceae & 14.25 & 14.69 & 8.11 \\
Zignemaphyceae & 10.28 & 22.20 & 17.81 \\
Chlorophyceae & 0.03 & 1.37 & 0,55 \\
Oedogonophyceae & 3.76 & 14.40 & 11.01 \\
Bacilariophyceae & 0.85 & 2.82 & 2.09 \\
Other algae & 0.01 & 0.49 & 0.19 \\
Invertebrate & $\mathbf{7 0 . 8 1}$ & $\mathbf{4 4 . 0 2}$ & $\mathbf{6 0 . 2 4}$ \\
Testate amoebae & 0.59 & 3.82 & 1.68 \\
Rotifera & 0.50 & 0.25 & 0.23 \\
Copepoda & 1.23 & 0.22 & 0.23 \\
Cladocera & 61.78 & 35.81 & 57.21 \\
Diptera & 5.53 & 3.35 & 0.40 \\
Other invertebrate ${ }^{* *}$ & 1.17 & 0.57 & 0.48 \\
\hline \multirow{2}{*}{. } &
\end{tabular}

**Hydracarina, Bryozoa, Ostracoda and Ephemeroptera.

Table 3. Pairwise comparisons for factor Time; Level 1 = Dawn; Level 2 = Light period; Level 3 = Dusk.

\begin{tabular}{ccc}
\hline Level vs. Level & $\mathbf{t}$ & $\mathbf{p}$ \\
\hline 1 vs. 2 & 3.3373 & 0.0002 \\
1 vs. 3 & 3.5928 & 0.0002 \\
2 vs. 3 & 1.3110 & 0.111 \\
\hline
\end{tabular}

represent a propitious habitat for foraging to small fish which feed mainly on algae and invertebrates, as evidenced by our results. In general, there is a direct relationship between invertebrate abundance and physical complexity of macrophytes (e.g., Thomaz et al., 2008). Other studies indicate that S. notomelas can also be associated with beds of other macrophytes species, such as Egeria spp. (Pelicice et al., 2005), or occur in multispecific beds (including Eichhornia spp.) (Casatti et al., 2003). In the same floodplain, but in a different period (2003 to 2005), S. notomelas was especially abundant in the macrophytes Cabomba furcata and Nymphaea amazonum (Dibble and Pelicice, 2010). The spatial distribution of animals results from a compromise between several costs and benefits, especially the avoidance of predation and the search for optimal feeding and environmental conditions (Iglesias et al., 2007)

The mean stomach fullness values were consistently high independently of the period showing that the flooding regime did not affect the feeding activity of $S$. notomelas. On the other hand, the mean stomach fullness values were significantly higher in the light and dusk periods indicating a more intense feeding activity in these periods. This finding is in accordance with those by Pelicice and Agostinho (2006) who observed marked diel feeding patterns for seven small-sized fish species associated with the submersed macrophyte Egeria spp., the majority of which presented diurnal activity, and only one was strictly nocturnal. However, different patterns can be found in other small fish species. For example, tetra fishes (small-bodied) have more intense activity during the night, probably as a behavioral response to decrease in pressure by the visually oriented predators (Gelós et al., 2010).

The diet of $S$. notomelas was composed exclusively by aquatic resources, and differed significantly between high (mainly Cladocera) and low (mainly algae) water periods, showing the effects of flooding regime in the diet composition of this species. This finding differs from others: for example, this fish fed predominantly on algae in macrophyte beds in the Rosana Reservoir, and in some isolated lakes of the Paraná River, independently of the period of the year (Casatti et al., 2003; Pelicice and Agostinho, 2006; Hahn and Loureiro-Crippa, 2006). However, the Rosana Reservoir is not under the influence of seasonal water regimes, and the samples in lakes of the Paraná River was carried out in a dry year - 2001 (Loureiro-Crippa et al., 2009). Thus, besides showing the importance of flooding regime on fish diet our results highlight that $S$. notomelas diet varies in different ecosystems and under different conditions (e.g., dry versus rainy years).

The changes in the food used by $S$. notomelas are probably related to the temporal abundance of feeding resources, as indicated by density of the invertebrates which were collected together with fishes. In the low water, Rotifera and Testate amoebae were the most abundant groups while in the high water, Cladocera, Copepoda and copepodids predominated (C.C. Bonecker, unpubl. data). On the other hand, the Upper floodplain lakes have higher phytoplankton densities during low water periods (Carvalho et al., 2001). Thus, when Cladocera density was low and algae is highly abundant (low water), S. notomelas consumed mainly algae but when Cladocera was more abundant and algae is less abundant (high water), Cladocera became a common food resource. In addition, Diaphanosoma, Daphnia and Moina were among the main Cladocera consumed and they were also the most abundant in the zooplankton in this period (C.C. Bonecker, unpubl. data). In accordance with our results, another study carried out with the plankton in the Upper Paraná Lakes, showed that planktonic species such as 
Moina minuta and Diaphanosoma birgei are more abundant during the high water period (LansacTôha et al., 2004). Despite the elevated density of copepodids, these organisms were not used as food probably due to the small size. In addition, copepodids and Copepoda (a highly abundant resource which was less consumed), have better capacity to move than Cladocera, getting their capture more difficult (Fregadolli, 1993). Effects of hydrological regime on diet composition have been also observed in vegetated wetlands in the floodplain of Paraná River in Argentina, where most of the dominant fish species collected at low water phase was classified into algivore/detritivore category, whereas at the high water phase the abundance of invertebrate feeders fish tended to increase (fish consumed mainly microcrustaceans and insects in this period) (Neiff et al., 2009).

Diel variations of the consumed items may be the result of a tradeoff between predation avoidance and food availability. In the periods with low light intensity, especially in the dawn, $S$. notomelas probably consumes Cladocera in the border of macrophytes patches, where these organisms concentrate (C.C. Bonecker, unpublished). On the other hand, in the light period more algae was consumed, suggesting that the fish feeds in roots inside the patches where microalgae are highly abundant (Murakami et al., 2009). This finding can be explained by protection against visual predators, i.e., $S$. notomelas uses well structured habitats (E. azurea patches) as refugia when light is more intense. Another hypothesis to explain diel variation in $S$. notomelas diet can be associated with horizontal migration by some zooplankton organisms. Horizontal migration of the cladocerans Bosmina longirostris and Diaphanosoma birgie, for example, was observed by Iglesias et al. (2007) who found these organisms in higher densities in the submerged plant beds during the night. The last hypothesis is reinforced by findings of Pelicice et al. (2005), who observed that $S$. notomelas is resident and do not leave the macrophyte patches during day/night periods.

The feeding resources used by $S$. notomelas suggest the importance of $E$. azurea beds as feeding habitats for this species because the main feeding items consumed such as algae Oedogonophyceae, Zignemaphyceae and Cyanophyceae, are associated with E. azurea (Murakami et al., 2009). In addition, the Cladocera Diaphanosoma, despite being typically planktonic (Lansac-Tôha et al., 2004), can carry horizontal migration toward submerged plant beds (Iglesias et al., 2007). Accordingly, the movement of zooplankton organisms between the pelagial and littoral zones in lakes of Paraná River floodplain is more evident during the high water period (Lansac-Tôha et al., 2004).

We conclude that the flooding regime did not affect the feeding activity of $S$. notomelas, while the diet composition was highly associated with the flooding regime, and the main resources used by species are associated with $E$. azurea patches. Thus, we infer that $S$. notomelas needs a physicallystructured habitat to perform important ecological functions, such as feeding and refuge.

\section{Acknowledgements}

We express our appreciation to Nupélia (Núcleo de Pesquisas em Limnologia, Ictiologia e Aquicultura) and to PEA (Programa de Pósgraduação em Ecologia de Ambientes Aquáticos Continentais) for their financial support and infrastructure, and to the Brazilian Council of Research (CNPq and CAPES) for providing grants to N Carniatto, G Cantanhêde and NS Hahn. We thank Sidinei M. Thomaz for helpful comments on the manuscript, and Claudia C. Bonecker and Nadson R. Simóes for helping with zooplankton information.

\section{References}

ABUJANRA, F., AGOSTINHO, AA. and HAHN, NS. 2009. Effects of the flood regime on the body condition of fish of different trophic guilds in the Upper Paraná River flooding, Brazil. Brazilian Journal of Biology, vol. 69, p. 469-479. PMid:19738954. http://dx.doi.org/10.1590/S151969842009000300003

AGOSTINHO, AA., THOMAZ, SM., GOMES, LC. and BALTAR, SLSM. 2007. Influence of the Eichhornia azurea on fish assemblage of the Upper Paraná River floodplain (Brazil). Aquatic Ecology, vol. 46, p. 611-619.

ALMEIDA, VLL., HAHN, NS. and VAZZOLER, AEAM. 1997. Feeding pattern in five predatory fishes of the high Paraná River floodplain. (PR, Brazil). Ecology of Freshwater Fish, vol. 6, p. 123-133. http:// dx.doi.org/10.1111/j.1600-0633.1997.tb00154.x

ANDERSON, MJ. 2001. A new method for nonparametric multivariate analyses of variance. Austral Ecology, vol. 26, p. 32-46.

BINI, LM. 1996. Influência do pulso de inundação nos valores de fitomassa de três espécies de macrófitas aquáticas na planície de inundação do alto rio Paraná. Arquivos de Biologia e Tecnologia, vol. 39, p. 715-721. 
CARVALHO, P., BINI, LM., THOMAZ, SM., OLIVEIRA, LG., ROBERTSON, B., TAVECHIO, WL. and DARWISCH, AJ. 2001. Comparative limnology of South American floodplain lakes and lagoons. Acta Scientiarum Biological Sciences, vol. 23, p. 265-273.

CASATTI, L., MENDES, HF. and FERREIRA, KM. 2003. Aquatic macrophytes as feeding site for small fishes in the Rosana reservoir, Paranapanema River, Southeastern Brazil. Brazilian Journal of Biology, vol. 63, p. 213-222. PMid:14509843. http:// dx.doi.org/10.1590/S1519-69842003000200006

CUNHA, ER., THOMAZ, SM., EVANGELISTA, HBA., CARNIATO, J., SOUZA, CF. and FUGI, R. 2011. Small-sized fish assemblages do not differ between a native and recently established nonindigenous macrophyte in a Neotropical ecosystem. Natureza \& Conservação, vol. 9, p. 1-6.

DIBBLE, ED. and PELICICE, FM. 2010. Influence of aquatic plant-specific habitat on an assemblage of small Neotropical floodplain fishes. Ecology of Freshwater Fish, vol. 19, p. 381-389. http://dx.doi. org/10.1111/j.1600-0633.2010.00420.x

DIBBLE, ED. and THOMAZ, SM. 2006. A simple method to estimate spatial complexity in aquatic plants. Brazilian Archives of Biology and Technology, vol. 49, p. 421-428. http://dx.doi.org/10.1590/ S1516-89132006000400010

FREGADOLLI, CH. 1993. Seleção alimentar das larvas de pacu, Piaractus mesopotamicus Holmberg, 1887 e tambaqui, Colossoma macropomum Cuvier, 1818 em laboratório. Boletim Técnico do CEPTA, vol. 6, p. $1-50$.

GELÓS, M., TEIXEIRA-MELLO F., GOYENOLA, G., IGLESIAS C., FOSALBA, C., RODRIGUEZ, FG., PACHECO, JP., GRACIA, S. and MEERHOFF, M. 2010. Seasonal and diel changes in fish activity and potencial cascading effects in subtropical shallow lakes with different water transparency. Hydrobiologia, vol. 646, p. 173-185. http://dx.doi.org/10.1007/ s10750-010-0170-6

HAHN, NS. and LOUREIRO-CRIPPA, V. 2006. Estudo comparativo da dieta, hábitos alimentares e morfologia trófica de duas espécies simpátricas de peixes de pequeno porte, associados à macrófitas aquáticas. Acta Scientiarum Biological Sciences, vol. 28, p. 359-363.

HYSLOP, EP. 1980. Stomach contents analysis, a review of methods and their application. Journal of Fish Biology, vol. 17, p. 411-429. http://dx.doi. org/10.1111/j.1095-8649.1980.tb02775.x

IGLESIAS, C., GOYENOLA, G., MAZZEO, N., MEERHOFF, M., RODÓ, E. and JEPPESEN, E. 2007. Horizontal dynamics of zooplankton in subtropical lake Blanca (Uruguay) hosting multiple zooplankton predator and aquatic plant refuges.
Hydrobiologia, vol. 584, p. 179-189. http://dx.doi. org/10.1007/s10750-007-0599-4

JUNK, WJ. 1973. Investigations on the ecology and production-biology of the "floating meadows" (Paspalo-Eschinochloetum) on the Middle Amazon. Part II. The aquatic fauna in the root zone of floating vegetation. Amazoniana, vol. 4, p. 9-102.

JUNK, WJ., BAYLEY, PB. and SPARKS, RE. 1989. The flood pulse concept in river-floodplain systems. In DODGE, DP., org. Proceedings of the International Large River Symposium. Ottawa: Canadian Special Publishers Fisheries and Aquatic Sciences. p. 110-127.

KOVALENKO, K., DIBBLE, ED. and FUGI, R. 2009. Fish feeding in changing habitats: effects of invasive macrophyte control and habitat complexity. Ecology of Freshwater Fish, vol. 18, p. 305-313. http://dx.doi. org/10.1111/j.1600-0633.2008.00348.x

KRUSKAL, JB. 1964. Nonmetric multidimensional scaling: a numerical method. Psychometrika, vol. 29, p. 115-129. http://dx.doi.org/10.1007/BF02289694

LANSAC-TÔHA, FA., BONECKER, CC. and VELHO, LFM. 2004. Composition, species richness and abundance of the zooplankton community. In THOMAZ, SM., AGOSTINHO, AA. and HAHN, NS. The upper Paraná River and its floodplain: physical aspects, ecology and conservation. Leiden: Backhuys Publishers. p. 145-190.

LOUREIRO-CRIPPA, VE., HAHN, NS. and FUGI, R. 2009. Food resource used by small-sized fish in macrophyte patches in ponds of the upper Paraná River floodplain. Acta Scientiarum Biological Sciences, vol. 31, p. 119-125.

LUZ-AGOSTINHO, KDG., AGOSTINHO, AA., GOMES, LC. and JÚLIO-JUNIOR, HF. 2008. Influence of flood pulse on diet composition and trophic relationships among piscivorous fish in the upper Paraná River floodplain. Hydrobiologia, vol. 607, p. 187-198. http://dx.doi.org/10.1007/ s10750-008-9390-4

LUZ-AGOSTINHO, KDG., AGOSTINHO, AA., GOMES, LC., JÚLIO-JUNIOR, HF. and FUGI, R. 2009. Effects of flooding regime on the feeding activity and body condition of piscivorous fish in the upper Paraná River flooding. Brazilian Journal of Biology, vol. 69, p. 481-490. PMid:19738956. http:// dx.doi.org/10.1590/S1519-69842009000300004

McCUNE, B. and GRACE, JB. 2002. Analysis of ecological communities. Gleneden Beach: MjM Software.

MEERHOFF, M., IGLESIAS, C., TEIXEIRA-MELLO, F., CLEMENTE, JM., JENSEN, E., LAURIDSEN, TL. and JEPPESEN, E. 2007. Effects of habitat complexity on community structure and predator avoidance behavior of littoral zooplankton in temperate versus subtropical shallow lakes. Freshwater 
Biology, vol. 52, p. 1009-1021. http://dx.doi. org/10.1111/j.1365-2427.2007.01748.x

MELO, SM., TAKEDA, AM. and MONKOLSKI, A. 2002. Seasonal dynamics of Callibaetis willineri (Ephemeroptera, Baetidae) associated with Eichhornia azurea (Pontederiaceae) in Guaraná Lake of the Upper Parana River, Brazil. Hydrobiologia, vol. 470, p. 57-62. http://dx.doi.org/10.1023/A:1015617102463

MORMUL, RP., THOMAZ, SM., HIGUTI, J. and MARTENS, K. 2010. Ostracod (Crustacea) colonization of one native and one non-native macrophyte species of Hydrocharitaceae: an experimental evaluation. Hydrobiologia, vol. 644, p. 185-193. http://dx.doi.org/10.1007/s10750010-0112-3

MURAKAMI, EA., BICUDO, DC. and RODRIGUES, L. 2009. Periphytic algae of the Garças Lake, Upper Paraná River floodplain: comparing the years 1994 and 2004. Brazilian Journal of Biology, vol. 69, p. 459-468. PMid:19738955. http://dx.doi. org/10.1590/S1519-69842009000300002

NEIFF, JJ., POI DE NEIFF, A. and VERÓN, MBC. 2009. The role of vegetated areas on fish assemblage of the Paraná River floodplain: effects of different hydrological conditions. Neotropical Ichthyology, vol. 7, p. 39-48.

PADIAL, AA., THOMAZ, SM. and AGOSTINHO, AA. 2009. Effects of structural heterogeneity provide by floating macrophyte Eichhornia azurea on the predation efficiency and habitat use of the small Neotropical fish Moenkhausia sanctaefilomenae. Hydrobiologia, vol. 624, p. 161-170. http://dx.doi. org/10.1007/s10750-008-9690-8

PELICICE, FM. and AGOSTINHO, AA. 2006. Feeding ecology of fishes associated with Egeria spp. patches in a tropical reservoir, Brazil. Ecology of Freshwater Fish, vol. 15, p. 10-19. http://dx.doi.org/10.1111/j.16000633.2005.00121.x
PELICICE, FM., AGOSTINHO, AA. and THOMAZ, SM. 2005. Fish assemblages associated with Egeria in a tropical reservoir: investigating the effects of plant biomass and diel period. Acta Oecologica, vol. 27, p. 9-16. http://dx.doi.org/10.1016/j. actao.2004.08.004

PIANA, PA., GOMES, LC. and CORTEZ, EM. 2006. Factors influencing Serrapinus notomelas (Characiformes, Characidae) populations in upper Paraná River floodplain lagoons. Neotropical Ichthyology, vol. 4, p.81-86.

RODRIGUES, L. and BICUDO, DC. 2004. Periphytic algae. In AGOSTINHO, AA., RODRIGUES, L., GOMES, LC., THOMAZ, SM. and MIRANDA, LE., orgs. Structure and functioning of the Parana River and its floodplain. Maringá: Eduem. p. 125-144

SAVINO, J. and STEIN, RA. 1982. Predator-prey interaction between largemouth bass and bluegills as influenced by simulated, submerged vegetation. Transactions of the American Fisheries Society, vol. 111, p. 255-266. http://dx.doi.org/10.1577/15488659(1982)111<255:PIBLBA>2.0.CO;2

TAKEDA, AM. and FUJITA, DS. 2004. Benthic invertebrates. In THOMAZ, SM., AGOSTINHO, AA. and HAHN, NS. The upper Paraná River and its floodplain: physical aspects, ecology and conservation. Leiden: Backhuys Publishers. p. 191-205.

THOMAZ, SM., BINI, LM. and BOZELLI, RL. 2007. Floods increase similarity among aquatic habitats in river-floodplain systems. Hydrobiologia, vol. 579, p. 1-13. http://dx.doi.org/10.1007/s10750-006$0285-y$

THOMAZ, SM., DIBBLE, ED., EVANGELISTA, LR., HIGUTI, J. and BINI, LM. 2008. Influence of aquatic macrophyte habitat complexity on invertebrate abundance and richness in tropical lagoons. Freshwater Biology, vol. 53, p. 358-367.

Received: 25 May 2012 Accepted: 12 March 2013 